\title{
Radio-Frequency Wave Application in Esthetic Surgery of Head and Neck
}

\author{
Novak Vukoje ${ }^{1}$ and Jon Garito ${ }^{2}$ \\ ${ }^{1}$ ENT office "dr Vukoje", Petrovaradin, Serbia \\ ${ }^{2} \mathrm{PhD}$, Inventer the dual Frequency device and the RF electrodes,, USA
}

Submission: June 16, 2017; Published: June 21, 2017

*Corresponding author: Novak Vukoje, ENT office “dr Vukoje”, Petrovaradin, Serbia, Email: drvukoje@hotmail.com

\begin{abstract}
Four-megahertz radiowave surgery is a relatively new technology usage of which rapidly expands reaching superior results compared to other surgical techniques. Radiosurgery is an atraumatic method of cutting and coagulation of soft tissues that uses optimal low heat $4.0 \mathrm{MHz}$ source for numerous plastic, esthetic and cosmetic interventions which require surgical precision, penetration control and low temperature. This technology allows us to simultaneously cut and coagulate surrounding tissue with minimal lateral tissue alteration, without burning damage and with better wounds healing. This mode is used by the author in anatomical areas of high vascularity and for the deeper tissue of the head and neck.
\end{abstract}

The pure cutting wave form is ideal for skin excision with othoplasty and blepharoplasty when we expect ideal esthetic result. Coagulation is obviously paramount for any surgeon and can make the difference between a good and poor result. When he coagulates tissues in the head and neck, the surgeon is frequently close to significant structures such as nerves and vessels which must be protected. Ellman Sugitron 4,0 offers great advantages. One of the strongest points of the Ellman system is the large array of specialized electrodes. By bending the malleable electrodes we can use them at any angle or even around corners.

The Author has done surgical procedures on over 900 patients using this technique on different esthetic problems with satisfying results. In operative material dominate various skin growths (haemangioma, fibroma, wart, nevus, etc.), othoplasty, blepharoplasty, rhinoplasty and other numerous surgical procedures. Interventions were done under local or general anesthesia.

Aim: The aim of this work is to present our bservation about radioablation in heterogenous pathological process on head and neck based on our own experience.

Conclusion: Our results show that this technology have great advantage over other techniques (scalpel, laser, electrocouter) out of which the most important ones are simultaneous cutting and coagulation, coagulation in liquid medium, minimal thermal damage of lateral tissues, faster healing of wounds with excellent cosmetic results. If we want surgery without cut, cut without scar, Ellman Surgitron is the best choice.

Keywords: Radiowave surgery; Esthetic procedures; Othoplasty; Blepharoplasty; Remove different benign skin tumors

\section{Introduction}

The opinion nowadays is that future of plastic, esthetic and cosmetic surgery belongs to development of new methodologies and technologies [1]. This concept is essential and comes with the need for applicationsophisticated appliances aimed to achieve as optimum results as possible. From the surgeon point of view that means "beauty treatment" closer to the following conditions - to be minimized in invasion, easy to be done, economic and clinically accepted as successful. Opinion exists that ELLMAN Surgitron 4.0 Dual fulfils abovementioned conditions (Figure 1)

Treatment with radio-frequency waves is simple and easy, and device is designed to be transportable, comfortable for use even in ambulances. It is the latest treatment method in plastic surgery and surgery of soft tissues [2-5]. By using five different working regimes (cut, cut-coagulation, hemostasis, fulguration and bipolar), when correctly chosen, it gives great possibilities in medicine and surgery (Figure 2).

When precision, safety and esthetics quality is requested, we use Surgitron 4,0 MHz. Scarce tissue is minimized and cosmetics result is superior. For elimination of benign changes on skin (on skin surface, above surface, pigmented, non-pigmented, vascular etc.) priority is given to radio surgery. Using "shaving" method benign changes can be eliminated. Malignant changes on skin can be eliminated by excision (Figures $3 \& 4$ ). As consequence of burnings on wound, after the treatment 


\section{Global Journal of Otolaryngology}

with classic electro-surgery devices, healing is postponed and by Surgitron that is not the case.

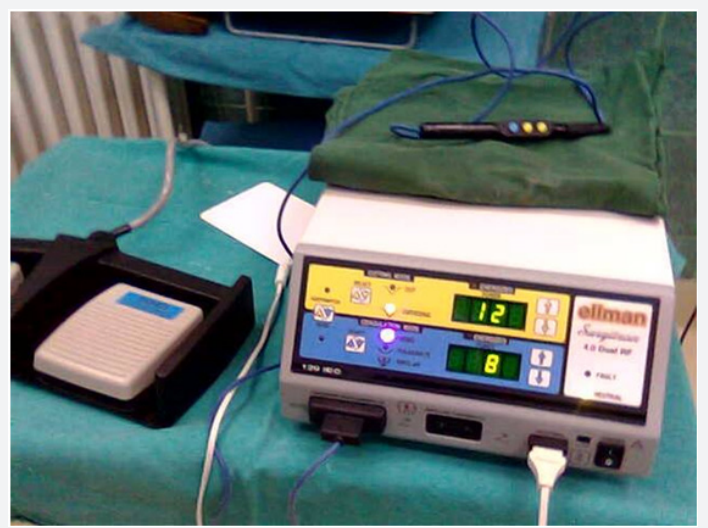

Figure 1: Ellman Surgitron 4.0 Dual RF, patented by Ellman International Company, Oceanside, New York, USA. Inventor dr Jon C. Garito, Patent reference number\# 5.954.686. USA. This was the worlds first discovery of the 4 Mhz Radiofrequency device.

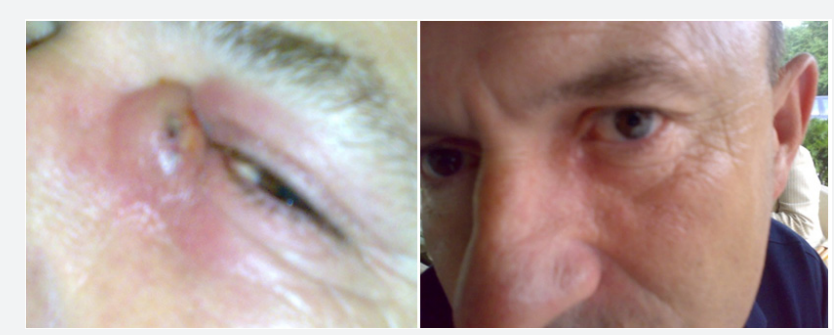

Figure 2: Medial eye-angle before and ten days after intervention.

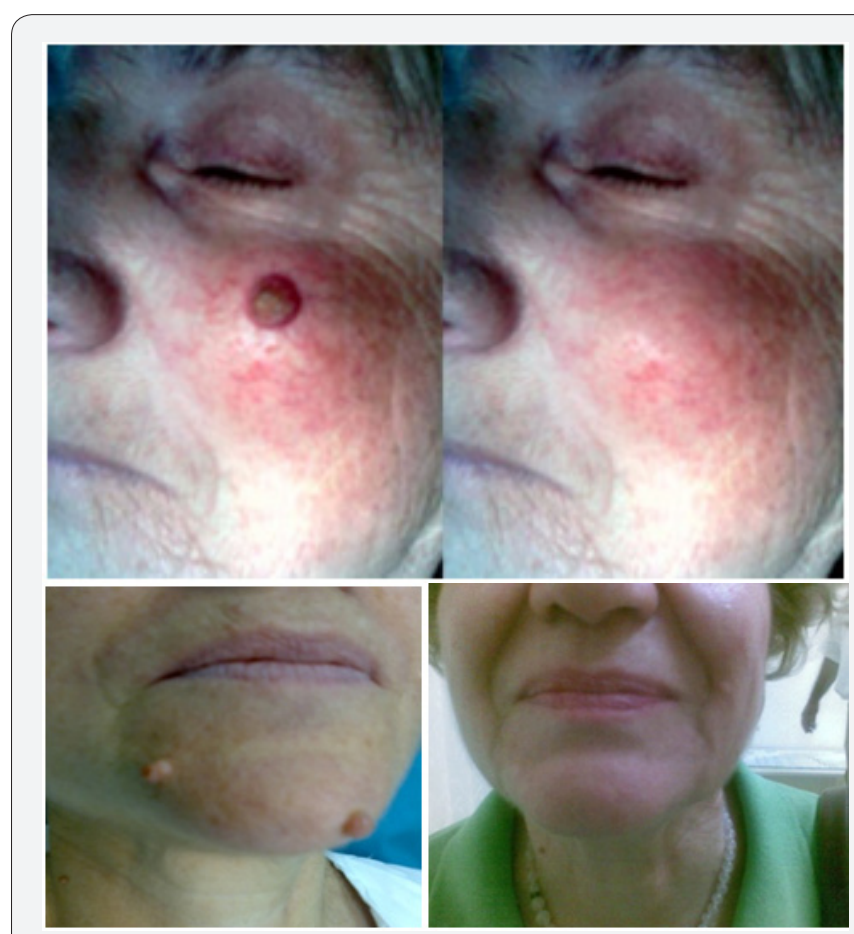

Figure 3: Excellent cosmetics result, aside of years. Face before and two weeks after nevus and dermatofibroma ablation.

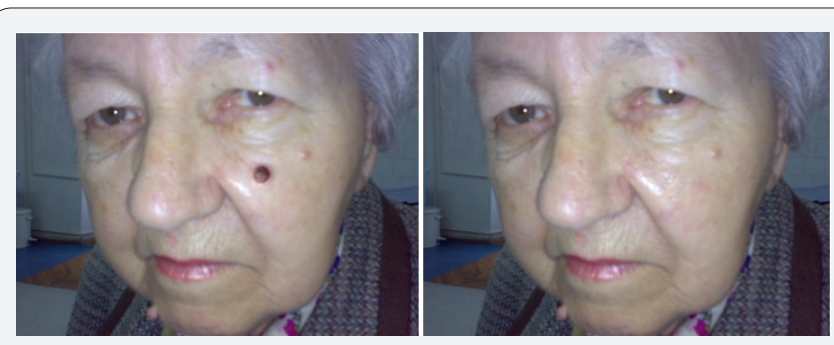

Figure 4: Surgery without cut. Radio wave ablation of senile papilla before and eight days after intervention.

Contents of cell (plasma) will be easy absorbed via blood vessels and in surgery with radio-waves on $4 \mathrm{MHz}$ there exists nil of necrotic tissues that postpone healing of wound and prologue visibility of scar. When frequency rises, degree of lateral tissue carbonization falls. That means that $4.0 \mathrm{MHz}$ Surgitron generate least of aside damages on tissue. Comparing to the laser, electrocouter, ultrasonic knife and other electronic devices, Surgitron functions completely different. During radio wave passage through active electrode, electrode does not get hot as in case of electrocouter where electrode can get extremely hot and melt itself from extreme temperature. In radio wave surgery, tissue is one that gives resistance, not electrode [6-8]. In core, in generator electricity transforms and converts in numerous wave modes that travel through tissue making planned procedure. Passive electrode that is in contact with patient's skin absorbs released energy and brings it back in device. It is of utmost importance to put neutral antenna as close to the treatment area as possible. Passive electrode used in radio wave surgery does not need to be always in direct contact with the patient. Covered with Teflon, there is no danger from electro-shock or burnings (Figure 5).

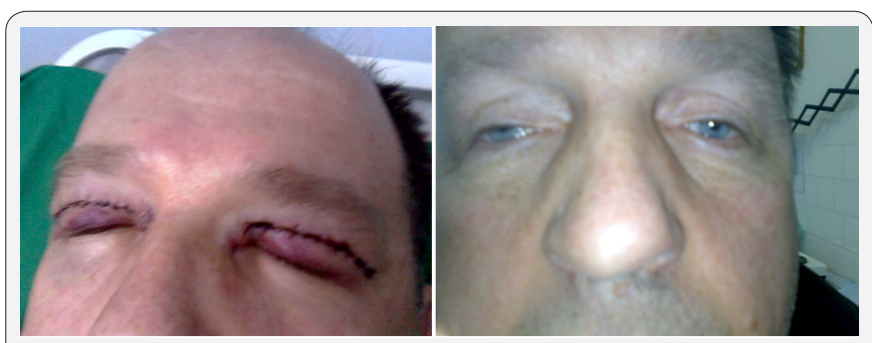

Figure 5: Cut without scar. Radioblefaroplastics (of upper eyelid) after wound suturetion (left) and three weeks later (right).

Using radio wave micro fiber electrode, micro-incision can cut tissue with utmost precision, and low temperature emitted during that time on surrounding tissue does not border optimal healing of wound. For many of surgeons hemostasy is great problem and can make differences between good and bad results [9]. When coagulation is made close to the important structures, as nerves or blood vascularity area, priority is given to the radio waves. In those situations ball shaped electrode is find to 
be excellent. It can be shaped under different angles and, thanks to that, it can afford hemostasy in hard reaching regions, especially in caverns or under the flap, when direct visibility is hard to achieve (Figures $6 \& 7$ ).
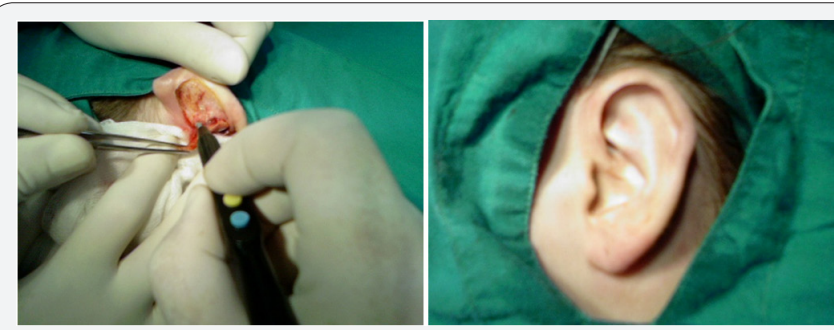

Figure 6: Bloodless operation. Radio-otoplastics active-left. Right - ear-shell sight soon after intervention (without edema and blood traces).

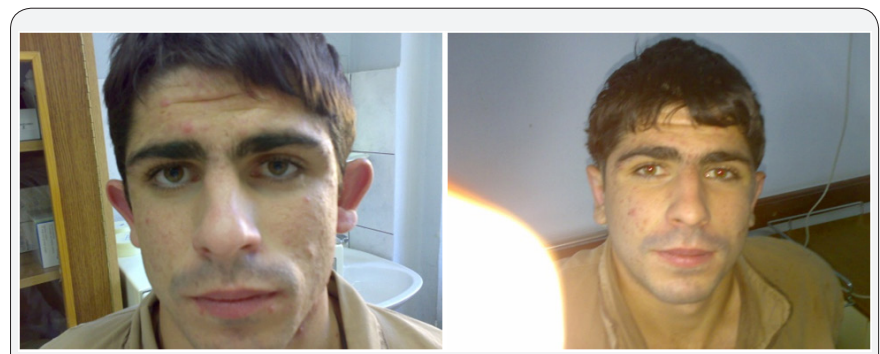

Figure 7: Otoplastics assisted Ellman Sugitron: before and ten day after procedure.

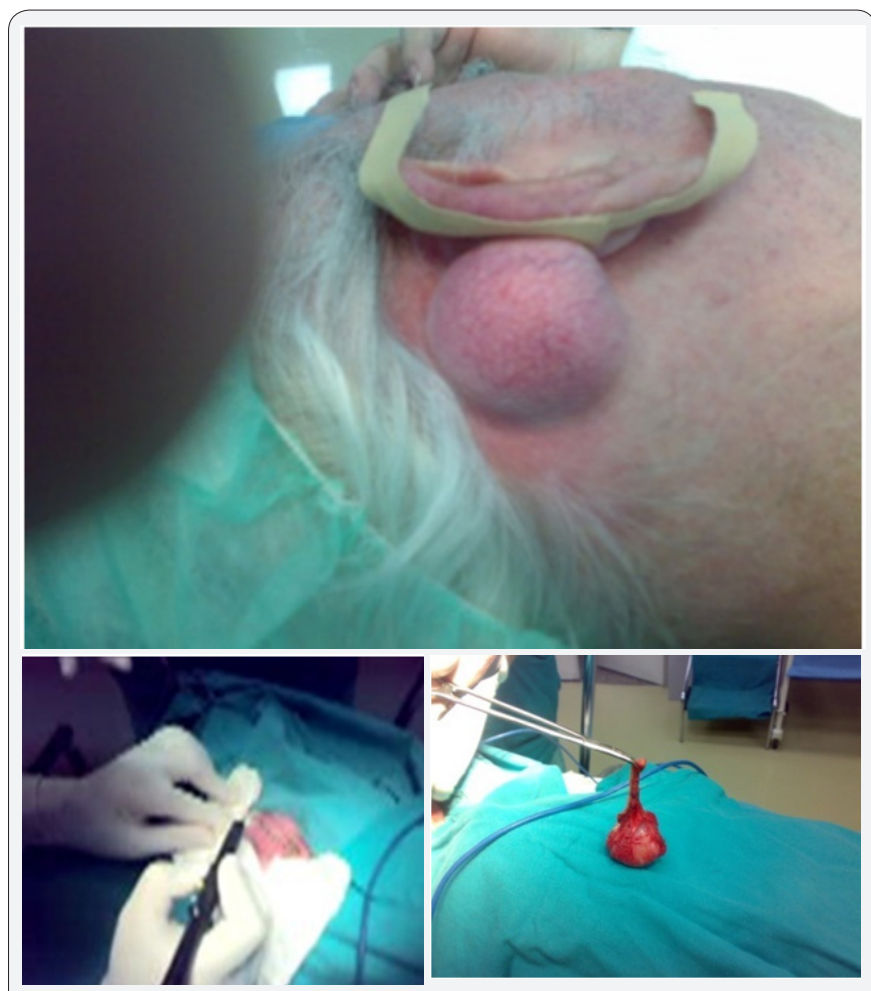

Figure 8: Skin and soft tissue incision without pressure. Extirpated retroauricle tumor. Localization for this technique is not important.

Because of blood presence in region, different surgical interventions on head and neck request use of that kind of technique. To surgeons, big assortment of electrodes makes their work safe and easy, and to patients fast returns to normal life activities. As in the case of other electro surgeon devices, radio wave surgery can also generate complications and dangers. The most frequent are aside tissue accidences and they are prerogative mistakes of surgeons [10]. Above-mentioned choose of optimal voltage, appropriate electrode, mode, continually, can prevent complications by gently moving electrodes through tissue, without speed retard and rest. Smoke that comes during intervention can be easily absorbed. Radio-wave generators can interference other medical appliances, monitors and particularly patients with pacemaker. Up-to-date pacemakers do not pose problems and interventions with radio/waves are routine (Figure 8).

Characteristics of that technique are shaping incision according to patological-morfological substrate, what is hard to achieve in conventional way. Submucosis interventions (under mucous membrane in nose shells, soft palate, uvula, tongue etc.) used in snore therapy are unique technique of radio-wave surgery. To surgeons, interventions with radio waves on rinofime are of great help. During intervention in highly blood rich region as nose is, incision and hemostasy are simultaneously applied. During all time of intervention Surgitron works symmetrically on program combination with maximum power settled on middle scale. As knife, a special electrode is being used. Parts of skin with changes are put off, leaving region to become covered with new one. To patients with such kind of illness, that method and technique represent "gold standard".

\section{Conclusion}

At the end, let us mention some preferences of radio-wave surgery in contrast to other electro surgical interventions:
a) Incision without pressure on tissue
b) Simultaneously done incision and coagulation
c) Coagulation even in liquid environment
d) Submucosis interventions
e) Possibility of shaping active electrode according to anatomy variations of the treatment region

f) No danger from electro-shock or burning effect from passive electrode

g) Minimum of aside tissue accidence

h) Minimized bleeding

i) Faster healing

j) Wide spectrum of use in different medical disciplines 


\section{k) Suitable for work in ambulances \\ l) Economic in exploitation, etc.}

\section{References}

1. Naimtu J (2014) Esthetic Removal of Head and Neck Nevi and lesions with 4.0 MHz Radio-Wave surgery:A 30 year experiencece. Oral and Maxillofacial Surgery 72(6): 1139-1150

2. Niamtu J (2000) Cosmetic facial surgery. Oral Maxillofacial Surg Clin North Am 12: 771.

3. Niamtu J (2000) Cosmetic facial Surgery. Oral Maxillofacial Surg Clin North AM 12: 771.

4. Niamtu J (2001) Radiofrequency application in Cosmetical Facial Surg. PlastSurgProd 11: 52.
5. Sperli AE (1998) The use of radiosurgery in plastic surgery and dermatology. Surg Technol int 7: 437.

6. Bridenstone JB (1998) Use of ultra-hight frequency radiosurgery for cosmetic surgical procedure. Dermatol Surg 24: 397.

7. Fariba J (2013) Patient satisfaction and effecacy of accent radiofrequency for facial skin wrinkle reduction. J Res Med Sci 18(11): 970-975.

8. Vukoje N (2008) Primena radiofrekventnih talasa u estetskoj hirurgiji glave i vrata. Acta Med Sal 37(2): 137-142.

9. Vukoje N (2013) Primena radiofrekventnih talasa u hirurgiji glave i vrata. Stom informator 5: 23-28.

10. Vukoje N (2008) Rez za miran san. Medicinska knjiga 1: 263-276.
This work is licensed under Creative

Commons Attribution 4.0 License

DOI: $10.19080 /$ GJO.2017.08.555741
Your next submission with Juniper Publishers will reach you the below assets

- Quality Editorial service

- Swift Peer Review

- Reprints availability

- E-prints Service

- Manuscript Podcast for convenient understanding

- Global attainment for your research

- Manuscript accessibility in different formats ( Pdf, E-pub, Full Text, Audio)

- Unceasing customer service

Track the below URL for one-step submission https://juniperpublishers.com/online-submission.php 